\title{
The Role of Diplomacy in the Fight Against Terrorism
}

\author{
By Haris Pesto *
}

\section{Introduction}

This article is an attempt to open up the issue of the role of diplomacy in the fight against terrorism. Diplomacy has a significant and irreplaceable role in the fight against modern terrorism. What we think of as the core skills of diplomacy probably appeared at the very beginning of human civilization during the creation of first organized human communities. Although warfare and the use of weapons have been the most important means of foreign policy for thousands of years, the appearance of nation-states has necessarily led to diplomatic communication among them. As a result, it is possible to identify certain traditions of diplomatic practice in the ancient empires of China, India, Assyria, Egypt, Persia, etc. Diplomatic relations were regulated for the first time in ancient Greece, in which city-states persistently fought for hegemony, entering into and dissolving alliances and changing missions. The most significant inheritance from this tradition is the principle of the absolute inviolability of envoys. This principle was also subsequently assumed by Rome. Gaius Julius Caesar also demonstrated great diplomatic skills by applying the method that was later raised to the level of an axiom contained in the Latin proverb divide et impera, or divide and conquer.

Even during the Roman Empire, diplomacy played a role in the discourse on the peaceful management of international relations, mostly through negotiations between states, although it is important to note that diplomacy mostly preceded wars, instead of helping avoid them. It is beyond doubt that most diplomatic activities require extensive knowledge. In this context, diplomacy may be described as an intellectual activity based on continuous gathering and processing of information, its analysis, and making decisions based on the available information.

* Haris Pešto has worked in the Office of the High Representative in Bosnia-Herzegovina, for DynCorp International, in the Embassy of the United States in Sarajevo, and for the Regional Security Office on tasks related to security and anti-terrorism. Since 2007, he has been working as a Partnership for Peace Coordinator for the U.S. Department of Defense at the U.S. Embassy in Sarajevo. He is currently a doctoral candidate at the University of Sarajevo. 
Modern diplomatic practice represents a complex set of skills, institutional and extra-institutional international relations, which are not limited to formal contacts between representatives of governments of various countries, as opposed to traditional diplomacy. Today's diplomacy is much more a diplomacy that takes place between the representatives of citizens' associations, informal institutions, non-governmental organizations, intellectuals, analysts, and researchers, than diplomacy between two or more ministries of foreign affairs that is conducted through diplomatic missions in the relevant states. This, however, is not the only novel characteristic of modern diplomacy, although it results in numerous other characteristics of diplomatic communication.

Some other characteristics of modern diplomacy include an increasing emphasis on multilateral relations as opposed to bilateral relations, the increasing role of large international organizations as opposed to strictly inter-state negotiations, as well as the increasing impact of the globalization process on the drafting of agendas of international negotiations. Exactly for these reasons, modern diplomacy is called "multitrack diplomacy," where traditional actors are participating only to a relatively small extent, and other, new actors participate more and more on an increasing number of different levels with their own new methodologies, interests, access, and ideas.

The basic function of diplomacy is to represent a given country abroad, and to promote its interests and goals. Its purpose is to serve as the instrument for the implementation of foreign policy as defined by the responsible governmental bodies (the president, government, parliament, or other bodies authorized under the constitution), and through them by the political party that holds the majority. The implementation of foreign policy and supporting international relations with other entities (countries, international organizations, etc.) also implies the development of specific methods, such as diplomatic protocol, and the administrative apparatus to carry out these duties. In simple terms, the tasks of diplomacy are to represent, negotiate for, protect, and inform its country. If we take the historical perspective, it may be said that the development of international relations, the promotion of the position of individual states, and the prevention of war represent the most important activities of diplomacy. Along with traditional political relations, diplomatic activities also include economic, cultural, scientific, military, and other relations. Modern diplomacy, in addition to these traditional tasks, also deals with such issues as human rights, illegal migration, environmental protection, organized crime, and the fight against terrorism. 


\section{The Diplomatic Approach to the Resolution of Problems Stemming from Terrorism}

Diplomacy represents the most powerful tool—one possessed by every country-in the fight against modern forms of terrorism that have expanded beyond state boundaries. As a global problem, terrorism has exposed the entire planet to the threats posed by operations carried out by terrorist groups and organizations. An adequate and skillfully implemented diplomacy is the central factor that can consolidate all anti-terrorist measures in a compact and related whole. Political and diplomatic antiterrorist measures can contribute to the resolution of intractable conflicts, and should attempt to do so through the means of both public dialogue and so-called secret diplomacy. These methods prevent terrorist organizations from participating in mass movements that are seen as effecting both political and social change. Fostering change without resorting to violent means implies that a familiar characteristic of traditional movements is strengthened, while the impact of terrorist organizations is reduced. Partial or conditional amnesty can be granted to the members of some terrorist groups that are seen in their home countries as being part of liberation movements, further delegitimizing more violent terrorist groups, and diplomatic pressure can be exerted on countries and all other supporters of terrorist organizations (e.g., withdrawal of diplomatic staff from countries that provide financial or moral support to terrorism, termination of diplomatic relations with those countries, etc.).

Diplomacy therefore can play a major role in anti-terrorist activities in general, whether in agreements, negotiations, or even mediation processes aimed at finding peaceful anti-terrorist solutions. Those individuals in political and diplomatic positions are some of the highest-ranking figures in state and governmental bodies; thus, they can play a decisive role in diplomatic anti-terrorist activities, because they are able to:

- Ensure a standardized approach to the problem of modern terrorism through timely activities abroad, placing a focus on the obligation of countries not to provide material or political support to terrorist activities

- Insist on the removal of the causes of terrorism, regardless of the scope and intensity of its activity

- Provide data and evidence in the initial phase that can be used to confirm the presence of terrorist organizations and groups, in order to ensure international assistance and support for the fight against terrorism

- Conduct timely consultations with relevant regional, European, and global political stakeholders for the purpose of obtaining support for planned anti-terrorist activities. 
Although political support is easier to provide, military action against terrorism should always remain an option if diplomatic activities cannot prevent violence or the threat of violence. In addition to the activities mentioned above, political and diplomatic anti-terrorist activities also include efforts related to the causes of terrorism that the great powers and the United Nations have been informed about for the purpose of obtaining international support for the implementation of an efficient anti-terrorist action. It is very important to persuade national officials and representatives of international organizations to refuse to conduct any secret contacts with terrorists and to deny them support, especially material support (transit, safe harbor, purchase of weapons, and training of terrorists). It is equally important that governments of friendly countries provide public support to endangered countries for measures that are taken during anti-terrorist activities. Persistent diplomatic activity may help create the conditions for aggressive international criticism of countries that are benevolent towards terrorists, which may result in a change of attitude within these countries or their permanent withdrawal of support to terrorist groups. Modern diplomatic activity contributes to the fact that, during various gatherings (political, expert, and scientific) of international governmental and non-governmental organizations, terrorist groups are treated in compliance with the UN Charter and international conventions on fighting terrorism, which helps deny these groups the legitimacy that they seek. Political and diplomatic activities are thus an extremely important framework for national actions, but also for making decisions about the use of military units for anti-terrorist actions, in order to preserve general international support for the actions of security forces against terrorist activities.

\section{Negotiating and Terrorism}

Terrorism has also opened a new chapter in both internal and international negotiations. Governments are often forced to negotiate with terrorist groups, especially in cases of hostage taking. They negotiate with terrorists with the aim of making them relinquish their objectives and turn themselves in, or-if the terrorists are under government control or in prison-to assist in detecting further intelligence about the terrorist network and its intentions. This is a very specific type of negotiation: on the one side there is the state, and on the other individuals or organizations that are not formally recognized by the state, but that obtain the status of a negotiating partner through force or the threat of force.

Governments often offer terrorists a combination of safe surrender, amnesty, or reduction of sentences for previous criminal offenses, along with benefits and security guarantees for them or their family members. The purpose of these settlements is to reduce the number of terrorists and weaken their network. A side effect may be 
sowing distrust and suspicion among the terrorists. ${ }^{1}$

Having learned from the experience of the first round of government amnesties for terror groups, terrorists have applied counter tactics to render subsequent promises of amnesty ineffective. When terrorists are first captured, the government has a good chance of negotiating with them, offering them milder sentences in exchange for information. ${ }^{2}$ The Red Brigades were considered as the most ideologically committed of all major Italian terrorist groups, and the most irreconcilable group when it came to any kind of cooperation with the state. The peak of their power and activities was represented by the 1978 kidnapping and later murder of the Italian Prime Minister Aldo Moro. In this case, the state was confronted with a typical "prisoner's dilemma." First, the law provided the special prosecutor with extremely broad latitude to impose a wide range of sentences on those who were ready to cooperate. This ranged from freeing cooperating Red Brigade members without any sentence whatsoever, or imposing the minimum sentence possible, and including promises of protection from reprisals, to draconian sentences in cases of persons who refused to cooperate. Second, any communication among prisoners was made impossible. Third, and maybe most important, the mutual trust of the arrested persons was at a very low level.

The Red Brigades were relatively small groups of ideologically firmly committed like-minded persons who knew one another well. These groups combined to form a large and complex organization that recruited more marginal members in addition to pursuing its more general political goals. Some of these new members were simply thugs, brought in to do dirty work. Others were allegedly drug addicts. In any case, the Brigades' ideological goals meant far less to the newcomers than they did to those from the original nucleus. The arrested members of the Brigades, including the most orthodox ones, were aware of the fact that there was a significant possibility that other prisoners might testify against them. This provided a strong impetus to cooperate, and when a large number of members of the Red Brigades were in prison, the ball began to unravel fast.

1 The amnesty issued by President Aquino in the Philippines resulted in bloody purges among the insurgent and terrorist groups. Two amnesties in Colombia gave different results: the first succeeded, the second failed. In the case of the first amnesty, there were many terrorists who were ready to turn themselves in, and in the case of the second amnesty, there were not. Also, after the first amnesty, the most important terrorist groupsM-19 and FARC - significantly sharpened their security measures. Finally, the terrorists responded with bloody attacks to the second amnesty, in order to make the government recall the amnesty.

2 The best-known case of that kind is the Italian Penitence Law, which many persons consider crucial for the successful campaign against the Red Brigades in the period 1970-78. 
A similar attempt against terrorist groups in Germany in the 1970s did not lead to such results, for several reasons. There was no special prosecutor in place who had been granted sweeping powers. The prisoners had the opportunity to communicate (and coordinate their stories), and the arrested persons maintained their mutual trust, because they were a smaller, tightly connected group. ${ }^{3}$ As Živorad Kovačević writes, "All these cases point to a serious problem that democratic societies based on [the] rule of law are facing: to what extent it is justified to limit democratic postulates and individual freedoms in order to render possible [a] more efficient fight against organized crime and terrorism."4

Terrorists who belong to fundamentalist ideological, religious, or racist circles are generally those that are least prepared to cooperate. The very existence of suicide terrorist attacks demonstrates that no victim is off limits for members of such ideologically committed groups. Being fully indoctrinated and convinced of the justifiability of even the most brutal action, they will almost never decide to negotiate with the authorities when they are caught, because they believe that it would be the betrayal of a great goal. Neither the promised benefits resulting from cooperation nor the threat of the harshest possible sentence if they refuse to do so have any impact on them. This is why, in cases of these kinds of terrorism-whether domestic, regional, or international - it is most difficult to apply the "carrot-and-stick" method.

Kidnapping and hostage taking are common forms of terrorist acts, in which terrorists set the ransom and demand a certain action on the part of the government in exchange for freeing their hostages. Sometimes the demand is financial in nature, but in cases of political, ideological, or religious terrorism, the most frequent request is the release of fellow terrorists who are imprisoned and the guarantee of their own safe asylum, or a change in government policies that are seen as endangering their goals. In cases of kidnapping, the location of the terrorists is unknown, and they feel personally safe; in cases of hostage taking, the government is in control of the physical location, and the terrorists often face the possibility of a government action that may threaten their lives. These are situations with high stakes on both sides, in which the actors involved either win or lose in a very dramatic fashion. In case of the government, the dilemma is very complex: should they refuse to meet the demands of the

3 In the case of Operation "Sablja," after the murder of the Serbian Prime Minister Zoran Đinđić in 2003, the Italian experience was applied. A new law was adopted, which increased the powers of the police and investigatory bodies (including provisions for the extension of sentences, etc.). This law also rendered possible the appointment of a special prosecutor with expanded powers and introduced a program for witness protection, aiming at making the arrested persons cooperate for the purpose of discovering members of the criminal or terrorist network.

4 Živorad Kovačević, Međunarodno pregovaranje (International Negotiations) (Belgrade: Filip Viśnjić Diplomatska akademija MSP SCG, 2004), 437. 
terrorists and risk the death of the hostages, or yield to their demands and risk encouraging future terrorist acts? In cases of hostage taking, the situation is therefore more complex and delicate, since the negotiations regarding the liberation of hostages have to take place in the moment, under the strong glare of public attention. It is thus necessary for the government to simultaneously express two opposed and hardly compatible attitudes: primary care for the lives of the hostages and decisiveness in fighting terrorism. Živorad Kovačević writes:

Important elements for decision making are related to the assessment of the risks of a police action against the terrorists on the one hand, and the readiness of the terrorists to follow through on the threat and really kill the hostages, on the other hand, even although that also means their own death. The motive of the terrorists is crucial for this assessment: religious or other fanaticism, the fight for independence or autonomy, mental derangement, personal freedom or wish for money or publicity. ${ }^{5}$

This also has a significant impact on whether the group involved in taking the hostages is well trained and thoroughly indoctrinated-in which case the chances for a successful police action that does not the lives of the hostages are small-or amateurs, which increases the chances of success. Some research results suggest that only 1 percent of terrorists that have taken hostages gave up their stated demands. Terrorists show adaptable behavior - they adapt their actions to the demonstrated willingness and ability of the government to defeat them.

Smaller instrumental concessions during negotiations, such as providing food, ensuring safe surrender, and even safe passage (if the hostages were not hurt) did not directly result in any increase in terrorism. ${ }^{6}$ When efficient protection measures are taken, some types of terrorism become less common and effective. Air hijacking cases have become less numerous since the widespread introduction of airport metal detectors, as have attacks on embassies. Terrorists will always adapt to changed circumstances and find new goals in locations where the protection is weakest and the surprise factor greatest. Governments will always need more time to adapt their behavior to shifts in terrorist tactics than the terrorists will need to adapt to changes in

\section{Kovačević, Međunarodno pregovaranje (International Negotiations), 438.}

6 Terrorist acts in France had been rare for a long period of time until 1973, when the French bowed to the demands of terrorists during the seizure of their embassy in the Saudi Arabia. Over the next three years, the number of terrorist attacks against French targets tripled. As of February 1976, the French government began to apply a completely different policy to terrorist actions, as exemplified in three different cases: it killed a group of terrorists in Djibouti, extradited members of the Baader-Meinhof group to Germany (whereas previously it had granted them asylum), and it took a strict attitude toward cells of Croatian ultra-nationalist terrorists. 
security measures. Only the dramatic attack on the World Trade Center in New York opened the eyes of the U.S. government to what extent the security controls in American airports were inadequate, especially on domestic flights - an inadequacy that rendered the territory of the United States highly vulnerable.

Živorad Kovačević claims that when a country engaged in the fight against terrorism veers over into unselective repression not only of terrorists but also of those that peacefully oppose the politics of the government, or uses excessive means of coercion against persons suspected of sympathizing with or supporting terrorists as well as arrested terrorists, it is very probable that this will lead to new violence. ${ }^{7}$ Research results suggest that there is a direct link between torture of suspected and convicted terrorists and increases in terrorism. Extraordinary security measures or restrictions of civil liberties have also not led to any decrease in terrorism. A report from the United Nations' Counter-Terrorism Policy Group stated: "The United Nations has to ensure that the key preoccupation is the protection of human rights. Terrorism frequently thrives in locations where human rights are violated, which requires additional actions for fighting violations of human rights. The very [act of] terrorism has to be understood as a violation of fundamental rights. In all cases, the fight against terrorism has to comply with international obligations related to human rights."

\section{U.S. Public Diplomacy in the Fight Against Terrorism}

The United States possesses enormous military power, and has the capability to overpower most of the opponents it might have a conflict with, even if they do not have an ally in that conflict. However, there is some concern in the U.S. regarding their military power. There are four main reasons for this concern: understanding the limitations of military power; the motivations of other states and non-state actors to challenge the United States; a misunderstanding of the nature of the challenge to be faced, and thus a misunderstanding of the nature of the appropriate responses to that challenge; and a tendency to overlook the values that are at stake, the values that the U.S. aspires to embody.

After the terrorist attacks of 11 September 2001, the U.S. developed a new national security strategy in order to fight global terrorism. U.S. military power became the key weapon in this fight, and it was also used to prevent potential threats.

7 Kovačević writes: "Human rights have to be respected in the fight against terrorism. [Government activities] should be part of [a] three-segment strategy that will support global efforts to: (a) prevent dissatisfied groups from engaging in terrorism; (b) withhold the means for the execution of terrorist acts to groups and individuals; [and] (c) persist in a widely set international cooperation in the fight against terrorism." Kovačević, Međunarodno pregovaranje (International Negotiations), 439. 
Another weapon in the fight against terrorism that has often been neglected, however, is public diplomacy, which includes diplomacy and the use of information in order to influence foreign public opinion about the United States' foreign policy goals. The use of information and diplomacy, which are often referred to as forms of "soft power," may be considered part of the information war, which is conducted together with the "hard power" conflict that is carried out using military and economic means.

There are still no clear results regarding the success of the use of U.S. military power in Afghanistan and Iraq, but it has become clear that the United States is losing the war of ideas, and that the international public is starting to express doubts about the war on terrorism. For example, the pictures and videos that became public in Spring 2004 that showed the torture of Iraqi prisoners by U.S. troops in the Abu Ghraib prison in Baghdad had a severe negative impact on the United States' standing in Iraq and on the opinions of the foreign public when it comes to the war on terrorism. Also, as a result of these incidents, the U.S. damaged its credibility with Muslim publics across the Middle East, and Islamist extremists used these incidents of torture as an excuse to justify the murders of civilians in the United States. Hans N. Tuch, a retired foreign affairs officer of the U.S. State Department, defines public diplomacy as the "government process of communicating directly with foreign publics in an effort to bring about understanding of our current policies and national goals, our ideas and ideals, as well as for our institutions and culture." 8 Philip Seib, a professor of journalism and public diplomacy and the head of the Public Diplomacy Center at the University of Southern California, defines public diplomacy as "a government (and some non-state actors) reaching out to foreign publics, rather than confining itself to the government-to-government communication of traditional diplomacy." 9

According to the now-defunct United States Information Agency (USIA), the goals of public diplomacy and the methods used for their achievement can be thought of as follows: public diplomacy attempts to promote the United States' national interest and national safety through increasing understanding, spreading information, and having a meaningful impact on international publics, and on the expansion of dialogue between American citizens and institutions and citizens and institutions abroad. Public diplomacy includes two wider functions that are implemented by Foreign Service staff that have been specially trained for work in foreign countries.

8 Hans N. Tuch, "Understanding Public Diplomacy," Public Diplomacy Council (23 April 2009); available at http://publicdiplomacycouncil.org/documents-0

9 Philip Seib, "Toward a More Imaginative U.S. Public Diplomacy," The Huffington Post (12 August 2009); available at http://www.huffingtonpost.com/philip-seib/toward-a-moreimaginative_b_243054.html. 
This staff is mostly stationed in various U.S. missions abroad. These functions of public diplomacy are:

- Short-term: explaining the existing politics of the United States, forwarding of speeches of the U.S. President and Secretary of State and representatives of these officials during state visits

- Long-term: exchanges involving students, libraries, and American Studies programs; building relationships with writers and editors who accept American values; publication of academic journals in local languages.

These functions of public diplomacy were for decades among the responsibilities of the USIA. This agency was closed in 1999, and its functions were taken over by the State Department.

There is also a third function of public diplomacy, one that is intended to inform international publics. Reductions in its budget after the Cold War weakened the Voice of America (VOA) radio network to such an extent that the service broadcast its programming in Arabic only seven hours per day. In addition, this Arabic programming was broadcast in single dialect of Arabic. Given the vast number of dialects of Arabic, it is estimated that this programming would have been able to successfully reach only 2 percent of the world's Arabic-speaking population. Some of the basic means used by public diplomacy are printed publications, cultural exchanges, movies, television, and radio. Public diplomacy may be best understood as encompassing all efforts in the field of public information that were officially undertaken by the U.S. government directed at informing and shaping foreign public opinion with the aim of influencing their view of the U.S., U.S. citizens, and U.S. foreign policy goals.

After the fall of communism, many public diplomacy programs that had been implemented during the Cold War were no longer needed and were closed. ${ }^{10}$ The U.S. public diplomacy machine was able to direct its efforts to countries such as Cuba, North Korea, Vietnam, and China, in which forms of communism survived, but it nevertheless also devoted attention to former communist countries in Eastern Europe and the former Soviet Union. ${ }^{11}$

10 For example, the Radio Free Europe (RFE) network was no longer the only source of information outside Eastern Europe. Cultural and educational exchange was no longer limited to programs run by the government, because national borders had been opened for travel, trade, and exchange.

11 In the United States during the last decades of the twentieth century the budget for the implementation of public diplomacy had been slowly decreasing, so that the USIA budget was reduced by 30 percent from 1990 to 1992 . 
In 1998, the U.S. Congress adopted the Foreign Affairs Reform and Restructuring Act, whereby the USIA ceased to exist, and its role in public diplomacy was taken over by the State Department. With the closing of the USIA, the State Department assigned many of its functions related to public information programs to its cultural and information centers abroad or to departments of U.S. embassies, making them thereby available to the public. In terms of information, the Unites States was wholly unprepared at the moment of transition from the twentieth into the twentieth century for what happened on 11 September 2001.

George W. Bush was inaugurated as President of the United States in January 2001. President Bush made no new political decisions at the time related to the implementation of public diplomacy or international public information, but he decided to continue the programs and maintain the political directives that were in place from the administration of his predecessor, Bill Clinton. When it came to terrorism, domestically the United States focused on organizational changes in federal, state, and local law enforcement structures and the implementation of policies that included the application of new legislation to intelligence operations. With respect to the international scene, U.S. foreign policy was primarily focused on defeating terrorism abroad, not on dealing with the consequences of terrorism at home. Together with military actions directed against terrorism, there was renewed interest in public diplomacy activities abroad, with the aim to win the "hearts and minds" of foreign publics and to combat anti-Americanism in the Arab world.

The report of the 9/11 Commission suggests that the word war precisely marks the effort to eliminate terrorists in the location where they originate, but also requires a wide-reaching program of social mobilization. After the close of initial coalition operations in Afghanistan, the scope of military activities there was significantly reduced. It was therefore emphasized in the Commission's report that long-term success requires the use of all elements of government power: diplomacy, intelligence services, covert operations, legal departments, economic policy, assistance to foreign countries, public diplomacy, and defense. ${ }^{12}$ Then-President Bush appointed Charlotte Beers as the new Deputy Secretary for Public Diplomacy and Public Affairs at the U.S. State Department. The main product of her office was a twenty-five-page pamphlet titled "Terrorism Network." This pamphlet, which was distributed in thirtysix languages, included graphic photos showing the destruction on September 11, strong comments against Al Qaeda and the Taliban, and condemnations of terrorism by world leaders such as Kofi Annan, Tony Blair, and Jiang Zemin.

12 See the Final Report of the National Commission on Terrorist Attacks Upon the United States (Washington, D.C.: Government Printing Office, 2004); available at http://www. gpoaccess.gov/911/index.html. 
But Beers also initiated a public information campaign that aimed at presenting to the world a view of the Arabs living and working in the United States, and showing American tolerance of Islam. This department printed thousands of posters in a series entitled "Mosques of America," which were distributed globally. Through publications such as "The Life of Muslims in America," the State Department wished to show the diversity present in democratic societies, emphasizing the religious tolerance that exists in multicultural and multiethnic societies such as the United States. In relation to this, the State Department also organized conferences on religious pluralism. The goal of these activities of U.S. public diplomacy was to show the inaccuracy of the terrorists' message that the United States is an anti-Muslim nation.

President George W. Bush was personally engaged in public diplomacy after the terrorist attacks. Three days after September 11, President Bush had a leading role in the ecumenical religious service at the National Cathedral in Washington, D.C., but he was assisted in its implementation by prominent U.S. Muslim leaders. Several days later, President Bush visited the Islamic Center, a mosque in Washington, where he made statements related to his view of Islam as a religion of peace. Also, in November 2001, President Bush invited the ambassadors of the member countries of the Organization of the Islamic Conference (OIC) for a prayer meeting and breaking of the Ramadan fast in the White House.

For the time being, there is no sign of a more specific definition of the U.S. president's role in public diplomacy, a step that would significantly strengthen the United States' efforts in this area. If a clearer role for the president in public diplomacy were thought to be desirable, the key elements of such a role should be:

- Clarifying the policies regarding the U.S. government's efforts to communicate with the public abroad, and strengthening its abilities to do so

- Establishing an efficient structure for the coordination of the most important elements of civil and military public diplomacy

- Requesting that all regional committees for the coordination of policy from the National Security Council Policy Coordinating Committees assess possible consequences on public opinion and develop communication strategies in compliance with the selected policy when analyzing political options

- Directing public diplomacy resources, training programs, budget, and technology resources to the most effective destination, with particular attention to the relationship with non-governmental organizations (NGOs) 
- Establishing effective working relationships with international organizations, commercial media companies, and coalition allies

- Setting a schedule for specific goals and standards for the assessment of progress in achieving reforms. ${ }^{13}$

At the beginning of the war on terrorism, the White House established an agency called the Coalition Information Center (CIC), which had offices in Washington, London and Pakistan. The purpose of this agency was to inform the public on the Western allies' war goals and offer quick rebuttals of enemy claims about civilian victims and successes in the field. The CIC also supported the "Initiative of Afghan Women," which was aimed at enabling women to take positions in post-Taliban power structures, in order to emphasize the importance of the victory in Afghanistan for human rights and individual freedoms. The U.S. Department of Defense (DoD) took over the activities related to the hiring of individual agencies in order to participate in the information war on terrorism. The Rendon Group, which was led by John Rendon, the former executive director of the Democratic National Committee, is one of the examples of agencies hired by DoD. The Rendon Group (TRG) is a strategic consulting firm in the field of communication whose clients are foreign governments, as well as the CIA and DoD. The firm was hired by the U.S. government to create certain media products, conduct a global media analysis, and produce other media offerings that aim at influencing foreign public opinion.

TRG provided direct support to DoD after September 11 through the analysis of media in the Arabic-speaking world, such as Al Jazeera and Al Arabiyya. Also, TRG made proposals to DoD in relation to a method of parrying anti-American topics and messages. One of the projects designed by the Boston office of TRG was called "peace strengthening"; the goal of this campaign was linking high schools in the U.S. with schools in the Muslim world through the Internet in order to break the communication barrier and spread cultural understanding. In the field of public diplomacy and the information fight against terrorism, the State Department also hired its own consultants, with the aim of countering anti-American sentiment in the Middle East and strengthening its public diplomacy efforts. The then-Secretary of State, Colin Powell, appointed Edward Djerejian, a former U.S. Ambassador to Syria, as chairman of the Advisory Group on Public Diplomacy for the Arab and Muslim World. This group's report, which was published in October 2003, was titled "Changing Minds, Winning Peace: A New Strategic Direction for U.S. Public Diplomacy in the Arab and Muslim World." 14

13 Peter G. Peterson, "Public Diplomacy and the War on Terrorism," Foreign Affairs 81:5 (Sept./Oct. 2002); available at http://web.ebscohost.com/ehost/detail?vid=5\&hid=111.

14 Report available at http://www.publicdiplomacy.org/23.htm. 
The basic recommendations of the Advisory Group on Public Diplomacy included: Structural changes in internal agency processes, in order to include the State Department, the White House, the National Security Council, and other important institutions and bodies with the new presidential directive that was supposed to emphasize the importance of public diplomacy in these processes

- Increased participation by the U.S. Agency for International Development (USAID) and DoD in all aspects of public diplomacy programs and policy

- Additional gathering of funds and organization of professional staff in the field of public diplomacy with knowledge of the cultures, religions, and languages of the Middle East

- Increased use of information technologies to foster communication with Arab and Muslim societies, as well as the use of new methods for measuring the success or failure of public diplomacy efforts

- Offering more English language courses and other means of education, in order to ensure better chances for Muslim youth to get training for certain professions

- Expansion of the "American Corner" program and creation of new projects under the rubric of the "Library of American Knowledge," which are particularly available at universities in the Middle East. ${ }^{15}$

The advisory group's report also included proposals for the implementation of the recommendations mentioned above. For example, the group supported the increase in educational exchange programs not only at Arab universities, but also through better mutual coordination through the International Military Education and Training Fund (IMET) of DoD and USAID programs. The target group of this educational exchange would be the most important people in the government, education, military, and economic sectors of foreign countries, who would have the opportunity to travel to the U.S. and participate in various education and training programs. The advisory group was of the opinion that greater course offerings in American Studies at universities in the Middle East-as well as in Middle East Studies at U.S. universitieswould create a climate for better understanding and dialogue and would improve the exchange of opinions when it comes to cultural, political, and social issues.

15 Richard J. Kilroy, Jr., "Public Diplomacy: Government, Universities, and the War on Terrorism," Journal of Public Affairs (2005): 132. 
As opposed to "hard power," which is based on coercion and results from military and economic instruments, "soft power" is not based on coercion, but rather on the ability of a country to impose its will in coordination with other countries by using the attractiveness of its culture and values, ideas and institutions. When a country has such an impact that it is able to motivate other countries to accept the same values, then such a country may be classified as one of the leading countries on the global stage.

"Soft power" also includes propaganda, but its scope is wider than that of propaganda itself. It includes real power-that is, the ability to achieve a goal. When a country is capable of persuading other countries of the validity of its ideas and values, and of creating a situation in which other countries wish to have the same goals and wishes, then the use of "hard power" is rendered unnecessary, and the "carrot-andstick" approach becomes obsolete.

According to Joseph S. Nye, a country's "soft power" is composed of three elements: its culture, which for some means popular culture, and for others language, classical music, literature, science, and educational or technological achievements; its dominant political values, based on which it is possible to see the impact of domestic policy on the way in which the country is seen abroad; and its foreign policy in situations in which it is seen as legitimate and possessing moral authority, making it possible to see the emotional impact of media reporting on actions implemented abroad.

Until 2000, the "soft power" of the United States was strong. The attractiveness of U.S. society and institutions was based on the country's great economic power. In part fostered by this economic strength was the pronounced domination of American business and culture, including television, movies, and music, as well as a widespread interest in immigration to the United States. During that period, U.S. foreign policy relied upon both soft and hard power. However, as of September 2001, the United States' level of soft power began to decline, due to the controversial policies of the Bush Administration that relied upon more aggressive use of diplomacy and military power. Programs in public diplomacy and cultural exchange were neglected as a result, which led to a failure in the promotion of U.S. society abroad.

Since 2001, U.S. foreign policy has become extremely unpopular abroad-especially during the last Iraq War-thereby strengthening anti-American feelings and causing a further decline in American soft power. There is consensus on the fact that both hard and soft power are extremely important for U.S. foreign policy and its fight against terrorism. Prevention of the expansion of terrorism and the achievement of various other goals, including efforts to promote democracy abroad, require the willingness to help other countries and peoples. In addition, there are places where the United States cannot go in search of terrorist leaders. In such situations, wider 
cooperation in the field of information gathering and prevention of terrorist financing is necessary. In other words, the United States' neglect of its soft power has limited its ability to persuade and influence others. In an era of global communication, there is a noticeable increase in the importance of "soft powers" of all varieties. Increases in the speed and reach of communication technologies have led to a "shrinking" of the world and have created ideal conditions for the expansion of soft power through information control.

Polls conducted in 2005 showed that many people believed that Europe and China play much more positive roles in the world as compared to the United States, which led to a decline in the popularity of the U.S. overseas. ${ }^{16}$ The Pew Charitable Trusts conducted a poll that showed that the perceived attractiveness of the U.S. drastically declined between 2001 and 2003 in nineteen out of twenty-seven countries. Negative attitudes towards the application of hard power by the Bush Administration even emerged in Great Britain, the United States' closest ally. The U.S. is currently trying to strengthen its efforts in leading a "softer" war on terrorism.

The initiatives of the State Department in the field of public diplomacy, such as the areas of educational and cultural exchange, have helped in drawing attention to many non-commercial aspects of U.S. values and culture, and have begun to influence public opinion abroad. However, the U.S. still has no coherent strategy in the field of public diplomacy that would make it possible to best present American values and most efficiently shape foreign public opinion. An important element of the United States' diminished attractiveness abroad is a lack of knowledge on the part of U.S. citizens about foreign countries. With the decline in its soft power capacity, the U.S. is also losing its power of influence.

In the attempt to achieve an impact on North Korea to make it renounce its production of weapons of mass destruction, the U.S. had to surrender the leading role to China. In the previous decade, due to the rapid growth of its economy, China had been trying to develop its own soft power by influencing other countries through regional assistance, public diplomacy, cooperation with multilateral institutions, and support for free trade. The Chinese Office of the Chinese Language Council International opened 135 Confucius Institutes around the world with the purpose of teaching Chinese language skills. This office is part of a wider campaign that includes investment and diplomacy and also cultural efforts with the purpose of speeding up China's development toward great power status. There are two mechanisms that can help the U.S. overcome the challenges of achieving a hegemonic position and therefore also strengthen their soft power.

16 For example, a poll conducted in 2005 by the Australian Lowy Institute showed that only somewhat more than 50 percent of Australians who were polled had a positive opinion about the United States, and approximately the same percentage of polled persons considered the foreign policy of the U.S. a threat. 
The first mechanism represents an approximately equal distribution of power in the international system, because the U.S., when facing an opposite power that is able to effectively counter them, would be forced to choose a much more conservative strategy instead of hegemony. Another limiting mechanism is the U.S. political system itself, which prevents government leaders from initiating unnecessary military ventures.

\section{Conclusion}

Diplomacy is the most powerful tool at the disposal of every country in the fight against modern terrorism, one that goes beyond state boundaries and is largely unhindered if not encouraged by globalization. Terrorist groups and organizations thus build their networks to span the entire world. Diplomacy, skillfully guided, represents the connective tissue that can incorporate all anti-terrorism measures into one compact and well-connected whole. Without efficient diplomacy, anti-terrorism measures and activities are fragmented and unconnected, and therefore also inefficient. In terms of the fight against modern terrorism, diplomacy does not relate only to professional diplomats working with their counterparts in governments abroad, but also to all officials performing other tasks specialized for and related to the fight against terrorism.

Diplomacy is a weapon in the fight against the new form of international terrorism that knows no boundaries. Terrorist groups are continuously expanding their scope of activities. The fight against a terrorist network such as the one including Al Qaeda requires the cooperation of numerous countries, since the network is active around the world. Efficient anti-terrorist diplomacy consolidates all these activities into a coherent whole.

Anti-terrorist diplomacy is not only the duty of professional diplomats in embassies and ministries of foreign affairs. Persons in charge of other specialized antiterrorist duties have to cooperate closely with their colleagues abroad. Regulatory agencies in charge of the safety of passenger air transport, for example, must perform a completely diplomatic function and ensure the necessary coordination in cases of overlapping of domestic and international security systems. Customs officers and immigration officers have the same task. The largest part of such specialized cooperation is implemented bilaterally, but multilateral diplomacy may also make a significant contribution. Multilateral diplomacy, which also includes UN resolutions and dozens of international conventions on terrorism, also improves international regulations against terrorism. Some conventions, such as the convention on airplane hijacking, represent the basis for practical cooperation in cases of overlapping national jurisdictions. There are clearly things that diplomacy is simply not capable of accomplishing 
in the fight against terrorism. Terrorists do not change their behavior as a result of a UN convention or resolution. But diplomacy supports all other tools that are used in the fight against terrorism, no matter whether it deepens the moral basis behind them, or whether it ensures the international legal framework for their use.

Financial oversight is an important tool in monitoring terrorist activities. By cutting off terrorists' access to financial resources, their activities can be reduced or even blocked, because the lack of resources makes it difficult for terrorists to plan operations. When we confront the challenge of stopping terrorist activities, we are faced with two great problems. One is that terrorism does not require significant financial assets; the other problem lies in the fact that it is extremely difficult to trace terrorist funds. Both of these represent an obstacle for all forms of the fight against modern terrorism. Diplomacy can to nothing to resolve the first, but it could have a significant impact on how we address the second challenge. 
THE QUARTERLY JOURNAL

\section{Bibliography}

Kilroy, Jr., Richard J.. "Public Diplomacy: Government, Universities, and the War on Terrorism." Journal of Public Affairs 132 (2005).

Kovacevic, Živorad. Međunarodno pregovaranje (International Negotiations). Belgrade: Filip Viśnjic' Diplomatska akademija MSP , 2004.

Peterson, Peter G.. "Public Diplomacy and the War on Terrorism." Foreign Affairs 81, no. 5 (2002).

Seib, Philip. "Toward a More Imaginative U.S. Public Diplomacy." The Huffington Post (2009).

Tuch, Hans N.. Understanding Public Diplomacy. Public Diplomacy Council, 2009. 